\title{
Review Article \\ Insight into Biological Apatite: Physiochemical Properties and Preparation Approaches
}

\author{
Quan Liu, ${ }^{1}$ Shishu Huang, ${ }^{2}$ Jukka Pekka Matinlinna, ${ }^{1}$ Zhuofan Chen, ${ }^{3}$ and Haobo Pan ${ }^{4}$ \\ ${ }^{1}$ Dental Materials Science, Faculty of Dentistry, The University of Hong Kong, Hong Kong \\ ${ }^{2}$ Department of Orthopedics and Traumatology, The University of Hong Kong, Hong Kong \\ ${ }^{3}$ Department of Oral Implantology, Hospital of Stomatology, Guanghua School of Stomatology, Institute of Stomatological Research, \\ Guangdong Provincial Key Laboratory of Stomatology, Sun Yat-sen University, Guangzhou 510080, China \\ ${ }^{4}$ Center for Human Tissues and Organs Degeneration, Shenzhen Institute of Advanced Technology, \\ Chinese Academy of Sciences, Shenzhen 518055, China
}

Correspondence should be addressed to Haobo Pan; hb.pan@siat.ac.cn

Received 6 May 2013; Accepted 29 July 2013

Academic Editor: Guoxin Ni

Copyright (C) 2013 Quan Liu et al. This is an open access article distributed under the Creative Commons Attribution License, which permits unrestricted use, distribution, and reproduction in any medium, provided the original work is properly cited.

\begin{abstract}
Biological apatite is an inorganic calcium phosphate salt in apatite form and nano size with a biological derivation. It is also the main inorganic component of biological hard tissues such as bones and teeth of vertebrates. Consequently, biological apatite has a wide application in dentistry and orthopedics by using as dental fillers and bone substitutes for bone reconstruction and regeneration. Given this, it is of great significance to obtain a comprehensive understanding of its physiochemical and biological properties. However, upon the previous studies, inconsistent and inadequate data of such basic properties as the morphology, crystal size, chemical compositions, and solubility of biological apatite were reported. This may be ascribed to the differences in the source of raw materials that biological apatite are made from, as well as the effect of the preparation approaches. Hence, this paper is to provide some insights rather than a thorough review of the physiochemical properties as well as the advantages and drawbacks of various preparation methods of biological apatite.
\end{abstract}

\section{Introduction}

Biological apatite is an inorganic calcium phosphate salt (CaPs) in apatite form with a biological derivation. As the main inorganic component of both bones and teeth, it is distributed in the organic constituents with certain sequence and direction [1]. By serving as the fillers in such biological tissues, biological apatite is critical to the physicochemical properties of the bulk materials. Meanwhile, it acts as the main mineral storage of vertebrates, participating in the dissolution and precipitation processes of CaPs, as well as the absorption and formation of bones, dentine, and cementum in vivo [2]. Additionally, due to the similarity in chemical compositions and structure, together with its outstanding bioactivity and biocompatibility, biological apatite has been used as bone substitutes for the reconstruction of bone defect in oral implantology, periodontology, oral, and maxillofacial surgery as well as orthopedics [3, 4]. Given the significant role of biological apatite in the structure and function of biological tissues and its clinical applications, numerous studies have been carried out in the investigation of its basic physiochemical and biological properties [5-19]. On one hand, with different approaches, biological apatite with varied size, shape, chemical composition, and solubility was obtained in these studies. On the other hand, in all these academic and clinical investigations, the preparation process of biological apatite is usually the first stage, which may probably have great influence on the observation and assessment of the resultant's characteristics. Given all above, this paper is to give some insight into the physiochemical properties and the preparation approaches of biological apatite. 


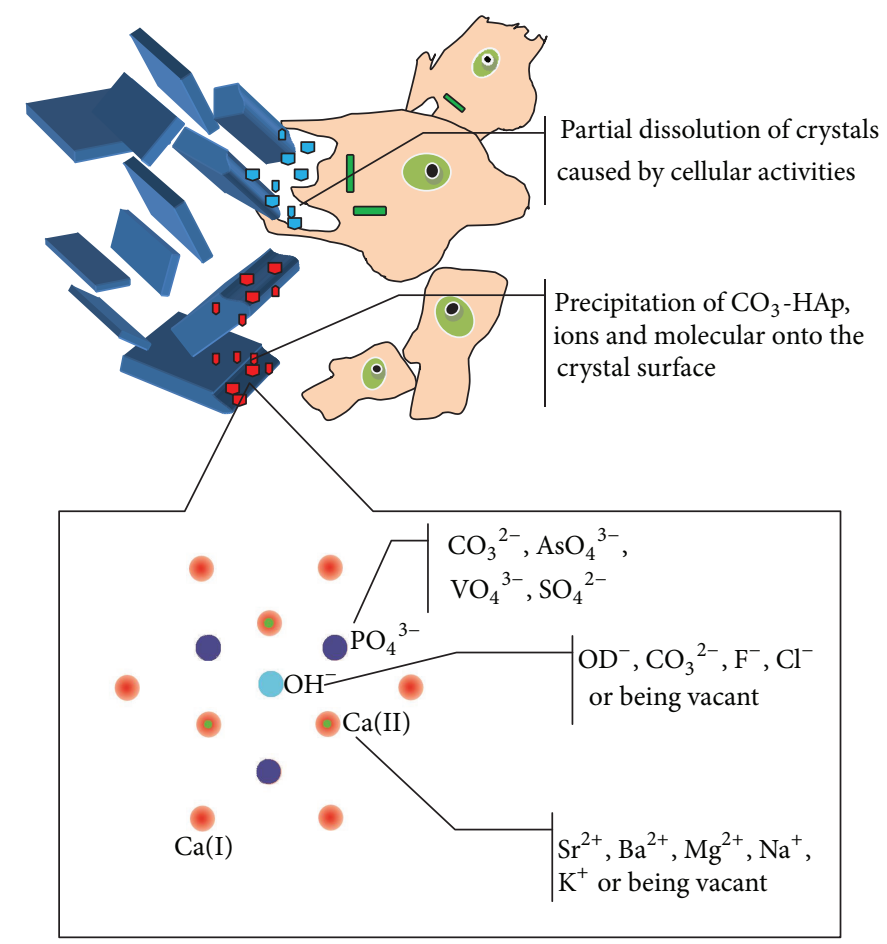

FIGURE 1: Schematic drawing of partial dissolution/precipitation of biological apatite in vivo and ionic substitutions in the crystal of HAp.

\section{Basic Characteristics of Biological Apatite}

2.1. Chemical Compositions. From a chemical viewpoint, biological apatite could be regarded as a ramification of hydroxyapatite (HAp), that is, calcium phosphate, in apatite form. As a representative member of apatites, HAp plays a significant role in various fields, such as soil chemistry [21], dental materials [22], caries etiology [23], bone mineralization [24], osteoporosis [25], and drug delivery [26]. As the precursor of biological apatite, the composition and structure of synthetic HAp have been studied extensively in previous reports [27-29]. Two different crystal forms were reported, that is, hexagonal with the lattice parameters $a=b=9.432 \AA$, $c=6.881 \AA$, and $\gamma=120^{\circ}$ [27] and monoclinic with the lattice parameters $a=9.421 \AA, b=2 a, c=6.881 \AA$, and $\gamma=120^{\circ}$ [28]. These two forms share the same elements, with a stoichiometric $\mathrm{Ca} / \mathrm{P}$ ratio of 1.67 . The major difference in their structure is the orientation of hydroxyl groups. In the hexagonal HAp, two adjacent hydroxyl groups point at the reverse direction; while in the monoclinic form, hydroxyl groups have the same direction in the same column and an opposite direction among columns [30].

The structure of apatite allows for wide compositional variations because of its ability in detaining different ions in its three sublattices [31]. In detail, the site of $\mathrm{Ca}^{2+}$ may be occupied by bivalent or monovalent cations such as $\mathrm{Sr}^{2+}$, $\mathrm{Ba}^{2+}, \mathrm{Mg}^{2+}, \mathrm{Na}^{+}$, and $\mathrm{K}^{+}$, whereas $\mathrm{P}$ could be substituted by atoms such as $\mathrm{C}$, As, V, S, while hydroxyl $\left(\mathrm{OH}^{-}\right)$may be replaced by $\mathrm{OD}^{-}, \mathrm{CO}_{3}{ }^{2-}, \mathrm{F}^{-}, \mathrm{Cl}^{-}$or even be left vacant [31] (Figure 1). Given this, the apatite may host carbonate in two positions: the hydroxyl sublattice producing type A carbonate apatite $\left(\mathrm{CO}_{3}-\mathrm{HAp}\right)$ and the phosphate $\left(\mathrm{PO}_{4}{ }^{3-}\right)$ sublattice forming type $\mathrm{B} \mathrm{CO}_{3}-\mathrm{HAp}$ [31]. In physiological environment, partial dissolution of CaPs occurs in the acidic microenvironment caused by cellular activities, leading to increased supersaturation of the biological or physiological fluid. Further, precipitation of $\mathrm{CO}_{3}$-HAp together with other ions and organic molecules occurs [32] (Figure 1). It is believed that biological apatite consists of a mixed substituted $\mathrm{CO}_{3}-\mathrm{HAp}$, in which $\mathrm{CO}_{3}{ }^{2-}$ ions are substituted for both $\mathrm{PO}_{4}{ }^{3-}$ ions (type $\mathrm{B}$, the major form) and $\mathrm{OH}^{-}$(type $\mathrm{A}$, the inferior form) [33].

In other words, biological apatite is a calcium phosphate framework incorporated by various sorts of ions. Calcium, phosphorus and oxygen are the three major elements composing the said framework. It was believed that the calcium/phosphorus $(\mathrm{Ca} / \mathrm{P})$ ratio of biological apatite was either lower than or close to that of stoichiometric HAp, namely, $1.67[15,29]$. However, it was also reported that the $\mathrm{Ca} / \mathrm{P}$ ratio could be even higher than the latter $[5,11,12]$. This may be ascribed to the difference in the treatment methods and conditions [14], the raw materials, and the test methods [12], as well as the detection error. Besides, carbon, sodium, potassium, fluorine, magnesium, aluminum, strontium, chloride, and some trace elements are also detected as incorporated ions in the biological crystals [29], although their content may vary among samples and sources, and the copresence of all these elements may not be always found. Such ionic substitutions could cause the difficulty in the measurement of the chemical compositions of biological apatite. Additionally, the dilemma in the determination of the chemical compositions is also worsened by ionic absorptions. For each crystal, these two effects may be distinctive, for 
its microenvironment in vivo may be unique. The location of absorbed trace elements can be hardly determined, that is, in the inorganic or the organic tissue of bones [34]. Furthermore, the incorporation and deposition of ions may increase with the age of crystals (namely, the elapsed time between the initial deposition of the crystal and its removal from the tissue), leading to a more complicated situation in the chemical compositions of biological apatite. In this case, the content of each element, especially the amount of chemical groups including $\mathrm{OH}^{-}, \mathrm{CO}_{3}{ }^{2-}, \mathrm{PO}_{4}{ }^{3-}$, and $\mathrm{HPO}_{4}{ }^{2-}$, in biological apatite may be substantially different from that in synthetic pure HAp.

Biological apatite shows its unique chemical compositions in two aspects, that is, the lacking of anticipatory hydroxyl group and the existence of $\mathrm{HPO}_{4}{ }^{2-}$ [34]. For hydroxyl group, it was reported that only a few percentage of the predicated concentration was detected in bone [35]. This was mainly explained by a charged compensation, which was initially caused by multiple ionic substitutions occurring in the lattice of biological apatite much often. The existence of $\mathrm{HPO}_{4}{ }^{2-}$ could be resulted from ionic substitutions as well. Moreover, it may also be ascribed to the hydrolysis of $\mathrm{PO}_{4}{ }^{3-}$ in solid phase [34]. However, up to now, it is nearly impossible to accurately measure the amount of such chemical groups including $\mathrm{OH}^{-}$and $\mathrm{HPO}_{4}{ }^{2-}$ due to the insufficient accuracy of analytical techniques [34]. This situation is worsened by the existence of a little known hydrated layer on the surfaces of the synthetic apatite crystals. The mineral ions consisting of such a layer were detected on the surfaces of biological apatite in nonapatitic arrays [36]. This layer is very difficult to be identified since the spectroscopic data of synthetic apatites have been found to be much more sensitive to partial and complete drying [34]. Similarly, the functional groups mentioned above can also be readily influenced by external factors such as temperature, $\mathrm{pH}$, inorganic solvent, and ionic effect. For instance, the apatite could lose carbonate groups after being sintered up to $850^{\circ} \mathrm{C}$ for 2 hours [5]. Inorganic solvent such as acid, even pure water, may cause partial dissolution of biological apatite crystals as well [13].

2.2. Crystal Morphology and Structure. The crystal structure of synthetic HAp was reported long ago [27], and most of the basic knowledge of the crystal structure came from single crystal X-ray diffraction (XRD) and neutron diffraction studies. However, for biological apatite, the analysis of single crystal structures had not been possible because of the absence of suitable single crystals for study [29]. Nevertheless, it was reported that the isolated crystals from natural bones were poorly crystalline apatite, similar to powdered intact bone from which they were originated [13]. Unfortunately, no crystal lattice parameters were stated in that study. In some subsequent studies, polycrystalline parameters were reported. The parameters of biological HAp prepared from bovine bone by sintering to $700^{\circ} \mathrm{C}$ were $a=b=9.429 \AA$, $c=6.885 \AA$ [37]. By contrast, the cell parameters of enamel in human and shark teeth were stated as $a=b=9.445 \AA$, $c=6.833 \AA$ and $a=b=9.377 \AA, c=6.881 \AA$, respectively [31].

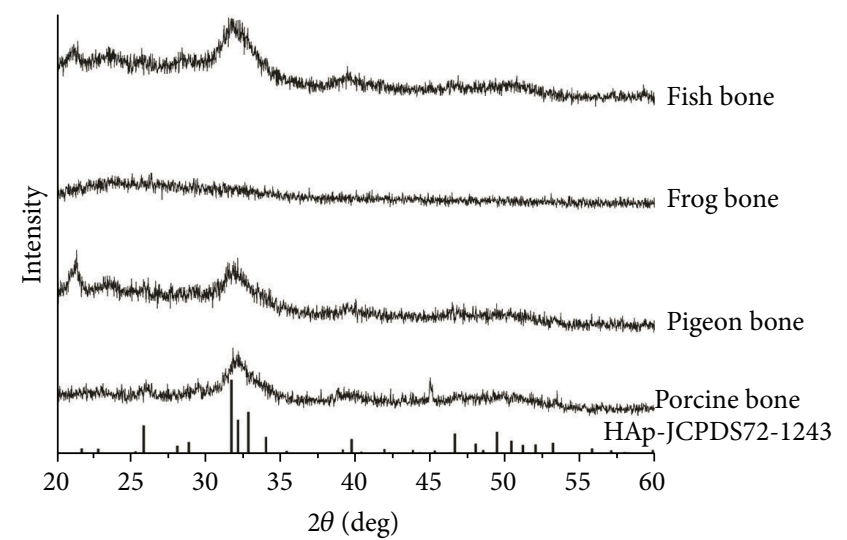

FIGURE 2: XRD patterns of animal bone-derived biological apatite: compared to the standard PDF card, the XRD patterns of the raw bones from various animals were hardly identified as HAp.

As to the shape of bone mineral crystals, it was reported that the crystals from bone sources were rod-like or needlelike in nanoscale $[5,38]$. However, some studies insisted that the original biological nanocrystals derived from various bones were in a similar shape of thin plate with wrinkled edges. It was also argued that the so-called rod-like or needlelike shape resulted from a special observation angle of the crystals as well as the probable transformation caused by heat treatment $[8,11,13,39]$. On the other hand, the crystal size of biological apatite had a great variety among reports and sources, from several $\mathrm{nm}$ to more than $100 \mathrm{~nm}[5,8$, $11,13,39]$. Additionally, it was believed that crystal size was highly related to the age of animal, especially the age of crystal. The crystal harvested from young postnatal animal was reported to be shorter and thicker than that from mature individual [18]. The conception of crystal age was specially emphasized by Rey et al. [34]. It was stated that there was a strong correlation between crystal age and its chemical compositions as well as morphology. Even for the same individual and the same bone, the biological apatite crystals varied from each other in age, resulting in the difference of structural and compositional properties.

As a matter of fact, the crystal size and crystallinity can also be readily affected by treatment methods and conditions. The crystallinity of biological apatite was found to increase with the sintering temperature of bovine bone [16]. The effect of treatment approaches to crystallinity was found in a previous study [5], which could be also proven by one of our recent studies: series of animal fresh bones were examined with XRD (Figure 2). It was found that the XRD patterns of fresh bones were hard to be identified, indicating a low crystallinity for all these animal bones. By contrast, the porcine bone treated with supercritical fluid $\mathrm{CO}_{2}$ extraction (SCF, $30^{\circ} \mathrm{C}, 35 \mathrm{MPa}, 2 \mathrm{~h}$ ) showed a slightly distinguishable pattern with higher intensity (Figure 3). Still, it was difficult to identify the crystal nature with this pattern alone. Another set of porcine bone was sintered up to $800^{\circ} \mathrm{C}$ for $2 \mathrm{~h}$, whose XRD pattern was fitted well with that of the standard PDF card of HAp (Figure 3). This demonstrated that a phase transformation together with crystal growth may 


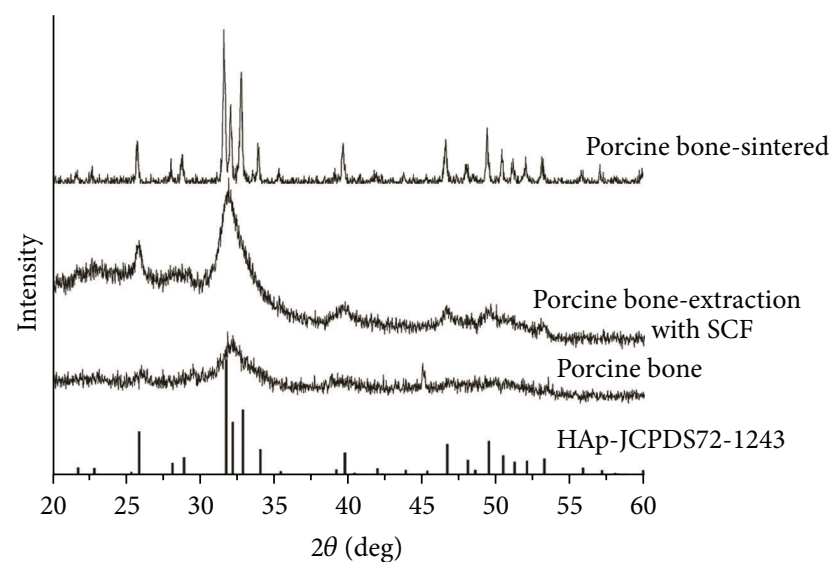

FIGURE 3: XRD patterns of biological apatite from porcine bone with different treatments: the XRD patterns of the raw porcine bone and those extracted with SCF were undistinguishable; the porcine bone sintered at $800^{\circ} \mathrm{C}$ for $2 \mathrm{~h}$ showed similar XRD patterns to the standard PDF card of HAp.

have been completed during the sintering process, indicating that the crystalline characteristics can be easily affected by the treatment approaches.

2.3. Dissolution Behavior and Solubility. As a matter of fact, the dissolution behavior and mechanism of biological apatite have been investigated since long time ago [40], and the solubility of biological apatite from bones and teeth has been extensively reviewed by Horvath [2]. That work drew a conclusion that comparable data of the solubility of biological apatite had been lacking, and there was a need for much more accurate solubility data. However, based upon a recent report, the solubility of bovine bone derived HAp (BioOss) was significantly higher than that of synthetic HAp [6]. This may be ascribed to the negative effect of the higher crystallinity of synthetic HAp than that of biological apatite. Additionally, it was also partially explained as the inner effect of carbonate on the structure and dissolution behavior of biological apatite, similar to that of carbon dioxide to the dissolution of HAp reported before [20]. On the other hand, the presence of magnesium in the biological apatite may contribute to the increased solubility compared to synthetic HAp [6]. Nevertheless, Bio-Oss was made from bovine bone by the extraction of organics at around $300^{\circ} \mathrm{C}$ according to the data from its manufacturer, indicating that such solubility data may not be the same to that of the original biological apatite due to the probable transformation such as crystal growth and recrystallization that resulted from such a high temperature and some other unknown conditions in the preparation process. Consequently, rare consistent solubility data for biological apatite are available up to now.

Given the complexity of biological apatite that resulted from the foreign ionic incorporations, synthetic stoichiometric HAp, with relatively simple structure and composition, has been taken as a simulative model for the investigation and assessment of the solubility as well as the ionic effects to the dissolution process of biological apatite [20, 41-47].

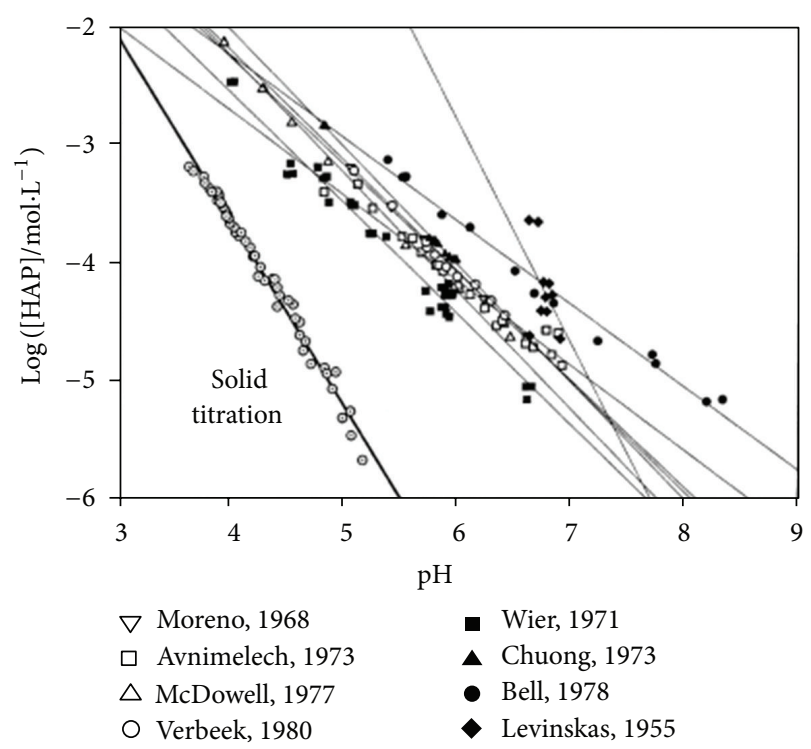

FIGURE 4: Solubility of hydroxyapatite with various methods [20].

Still, the dissolution of synthetic HAp appears much more complicated compared to that of simple salts since the former is incongruent. Several simultaneous parallel aqueous and surface reactions are involved in the dissolution process of HAp so that the classic thermodynamic theory could hardly explain the mechanism [48]. In this case, little agreement on the solubility and the definite dissolution mechanism has been achieved although numerous studies attempting to solve this problem have been carried out over the past few decades (Figure 4) [20, 46, 49, 50].

With respect to the research progress and discrepancy among different research methods about the solubility of HAp, it has been fully reviewed in some previous publications $[20,41]$, which could be summarized as follows.

Firstly, due to the incongruent dissolution of HAp and the complicated reactions in the dissolution system, it is inappropriate to determine its solubility and investigate the dissolution mechanism with the traditional methods [17] based upon excess addition of solid, long period of immersion, and the classic thermodynamic theory. The discrepancy of the reported solubility of HAp in the previous publications may be also caused by the differing compositions (including $\mathrm{Ca} / \mathrm{P}$ ratio) of the samples and the contamination of other phases (such as OCP, DCPD, and TCP), or ions (carbonate, especially).

Secondly, solid titration [20,41], as a reliable, precise, and reproducible method, can be used in the determination of the solubility of HAp as well as some similar complexes $[6,42]$. Compared with the traditional excess-addition approaches, solid titration is based upon the expectation of heterogeneous nucleation close to the point of saturation [51]. The solubility of HAp determined with solid titration was substantially lower than that previously reported [20, 41]. In the solubility isotherm of HAp, a change of the slope was found at $\mathrm{pH}$ $\sim 3.9$, which may indicate two different dissolution modules or phases at its two sides [41]. Precipitates at $\mathrm{pH}$ 3.2, 3.6, 
TABLE 1: Similarity between animal and human bone [59].

\begin{tabular}{lcccc}
\hline & Canine & Sheep/Goat & Pig & Rabbit \\
\hline Macrostructure & ++ & +++ & ++ & + \\
Microstructure & ++ & + & ++ & + \\
Bone composition & +++ & ++ & +++ & ++ \\
Bone remodeling & ++ & ++ & +++ & + \\
\hline
\end{tabular}

+ least similar, ++ moderately similar, +++ most similar.

and 4.1 were collected and identified as deficient-calcium $\mathrm{HAp}$, whose $\mathrm{Ca} / \mathrm{P}$ ratios appeared to decrease with the $\mathrm{pH}$ value [41]. Similar results were obtained in subsequent studies $[6,47]$, which was inconsistent with a previous report in which DCPD was presumed to be the stable phase below the singular point of DCPD/HAp at $\mathrm{pH} 4.3$ at $25^{\circ} \mathrm{C}$ [52].

Thirdly, the effects of $\mathrm{CO}_{2}$, strontium, and excess phosphate on the dissolution of HAp were investigated with solid titration as well. It was found that the solubility was increased by such ions to some extent $[20,42,47]$, indicating that the biodegradability of biological apatite may be improved with such ionic incorporations.

Although the solubility of HAp has been fully investigated, some outstanding problems related to the dissolution mechanism and the effect of some other factors should be resolved in further studies, which is of significance to the understanding of biological apatite. On one hand, the probable phase or complex during the dissolution process of HAp needs to be further identified. In some research models, for example, the metastable theory, probable surface complex or phase was presumed or even "proven" indirectly [53]. However, little direct evidence such as XRD patterns and SEM images has been obtained, although both stoichiometric HAp [53] and deficient-calcium HAp [54] were reported in different studies. On the other hand, the effect of ions and molecules on the dissolution behavior of HAp needs further investigation. Many studies have been carried out to investigate the effect of different ions and molecules on the properties of HAp [42, 47, 55, 56]. Nevertheless, some controversy remains and needs to be clarified.

\section{Preparation of Biological Apatite}

Biological hard tissues such as bones [11, 14, 16, 37, 57] and teeth [58] are the main raw materials in the preparation of biological apatite. For the commercial bone grafting products, most of the bone-derived substitutes are from bovine bone. However, other animal bones such as porcine and canine bones show great similarity in terms of macro-/microstructure, bone composition and remodeling to human bone (Table 1) [59], which could be alternatives for bone grafting materials. Moreover, the biological apatite from marine animals such as fishes has low crystallinity and high content of effective trace element such as strontium [60], indicating its potential as bone substitute as well. Nevertheless, to our knowledge, such rare animal bones have been used in the production of bone grafting materials.

In some basic studies, various raw materials (Tables 2 and 3 ) and preparation approaches were reported. The common mechanism is to eliminate the organic components of the raw materials with various methods, leaving the inorganic apatite for investigation, examination, and application.

3.1. Thermal Treatment. Thermal treatment may be one of the most straightforward methods in order to eliminate the organic components of biological materials. It depends on the oxidation of organics at high temperature. Usually, it is carried out in a furnace or oven, where the organics are burnt out and the apatite are obtained. The conditions for this process including time, temperature, and atmosphere of sintering varied among previous studies (Table 2). A series of annealing temperature from $400^{\circ} \mathrm{C}$ to $1200^{\circ} \mathrm{C}$ was used to investigate the change of bone blocks in color, crystal characteristics, morphology, and composition [16]. In that study, it was found that the organic components of the bone blocks were removed completely by heating the samples up to $600-700^{\circ} \mathrm{C}$ for $2 \mathrm{~h}$ [16]. By contrast, it was reported that nano-sized crystals of biological apatite were obtained from a cortical bone of rat after sintering the raw material up to $600^{\circ} \mathrm{C}$ for $24 \mathrm{~h}$, without any organic components residual [62]. Besides, $500^{\circ} \mathrm{C}$ and $700^{\circ} \mathrm{C}$ overnight were also applied in the preparation of biological apatite from bovine bones [37, 57], while the highest temperature reported was $1300^{\circ} \mathrm{C}$ for $2 \mathrm{~h}$ [14] or $45 \mathrm{~min}$ [8]. From all these studies, similar biological apatite was harvested although the heating temperature and period were inconsistent. This may be partially ascribed to the difference in the pretreatment (mainly chemical treatment) and oxygen condition as well as the size of samples. It can be assumed that lower temperature and shorter period might be required for the organic components elimination with some chemical pretreatments, sufficient oxygen, and smaller sample size.

With a simple procedure, relatively low requirement in equipment and a low risk in disease transmission of the resultant, thermal treatment seems a feasible method for the preparation of biological apatite. The annealing temperature and period depend on the sample size, oxygen supply, and some possible pretreatments. For a bone block in one cubic centimeter, a temperature range between $600^{\circ} \mathrm{C}$ and $1000^{\circ} \mathrm{C}$ for $2 \mathrm{~h}$ may be enough to eliminate the organic components [16]. Meanwhile, a probable decomposition from HAp to $\beta$ TCP occurring at more than $1000^{\circ} \mathrm{C}$ could also be avoided under this condition [16].

Nevertheless, attention should be paid to the probable change occurring to the crystals of biological apatite from its original form. It is difficult to identify when and how many such a change occurs during the thermal treatment process, for the direct strong evidence was still lacking. However, upon an $X$-way investigation, it was found that the most significant change in the structure of biological apatite occurred between $600^{\circ} \mathrm{C}$ and $800^{\circ} \mathrm{C}$, including a great increase of crystallinity and the disappearance of microstrain [67]. Besides, as to the possible effect of sintering temperature to the crystal characteristics, hint could also be drawn from some studies on synthetic HAp. It was reported that the morphology and crystal size of synthetic HAp were changed by heat treatment up to $650^{\circ} \mathrm{C}$ [68]. This was also observed in our recent study. HAp was synthesized with hydrothermal method and then 


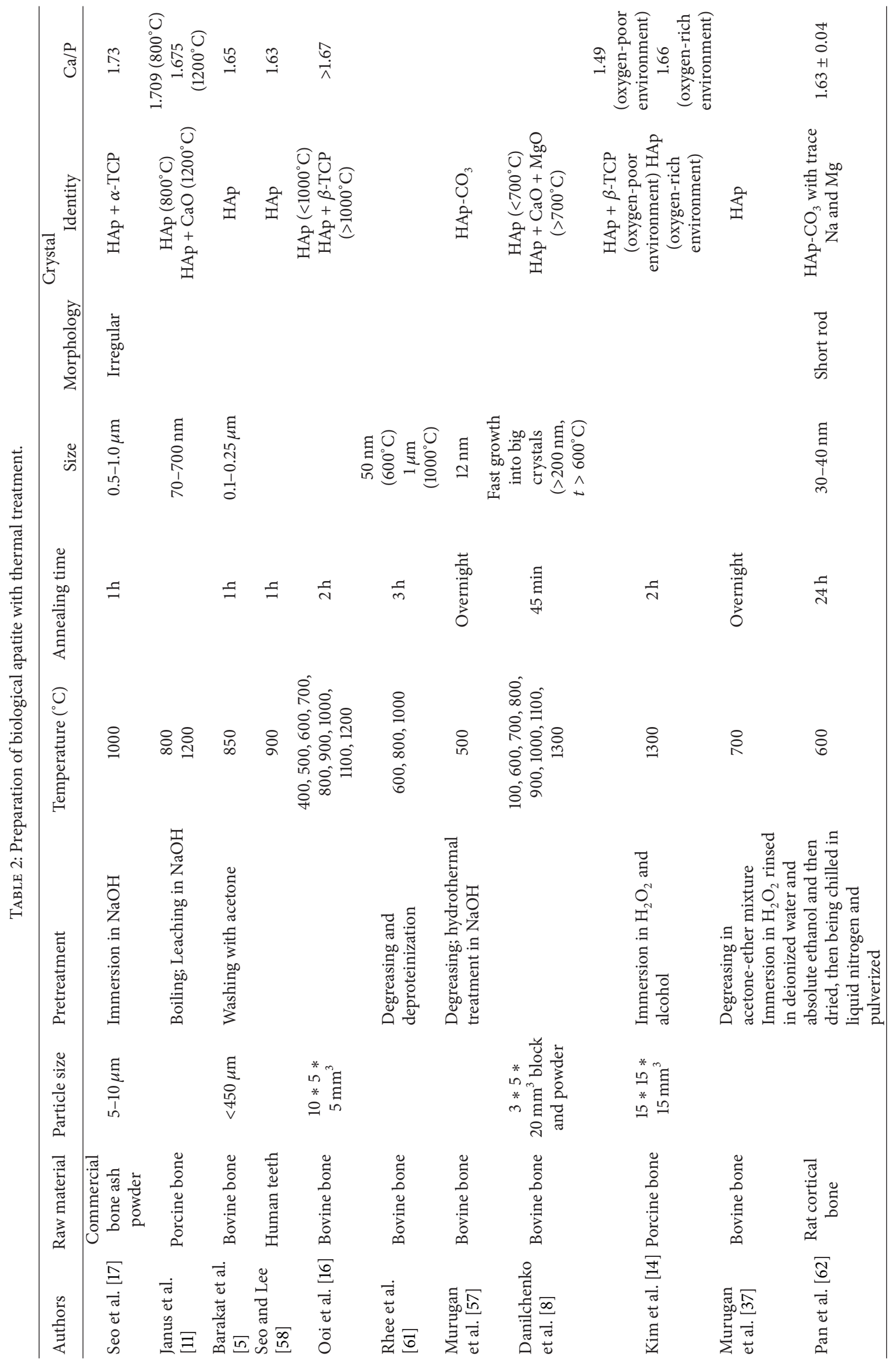


TABle 3: Preparation of biological apatite with plasma ashing.

\begin{tabular}{|c|c|c|c|c|c|c|c|}
\hline \multirow{2}{*}{ Authors } & \multirow{2}{*}{ Raw material } & \multirow{2}{*}{ Sample size } & \multirow{2}{*}{ Pretreatment } & \multirow{2}{*}{ Ashing time } & \multicolumn{3}{|c|}{ Crystal } \\
\hline & & & & & Size & Morphology & $\mathrm{Ca} / \mathrm{P}$ \\
\hline $\begin{array}{l}\text { Li et al. } \\
\text { [63] }\end{array}$ & $\begin{array}{l}\text { Goat bone } \\
\text { powder }\end{array}$ & & $\begin{array}{l}\text { Degreasing in } 2: 1 \\
\text { chloroform and } \\
\text { methanol mixture }\end{array}$ & $15 \mathrm{~h}$ or more & $8-10 \mathrm{~nm}$ in width & $\begin{array}{l}\text { Plate-, rod-, } \\
\text { needle-like }\end{array}$ & \\
\hline $\begin{array}{l}\text { Kuhn et al. } \\
\text { [15] }\end{array}$ & $\begin{array}{l}\text { Bovine tibia } \\
\text { and femur }\end{array}$ & $<75 \mu \mathrm{m}$ & $\begin{array}{l}\text { Degreasing in } 2: 1 \\
\text { chloroform and } \\
\text { methanol mixture }\end{array}$ & 40 days & & & $\begin{array}{c}1.51 \text { (younger } \\
\text { cancellous } \\
\text { bone) } \\
1.61 \text { (younger } \\
\text { cortical bone) } \\
1.58 \text { (older } \\
\text { cancellous } \\
\text { bone) } \\
1.64 \text { (older } \\
\text { cortical bone) }\end{array}$ \\
\hline $\begin{array}{l}\text { Kim et al. } \\
\text { [39] }\end{array}$ & Chicken bone & & $\begin{array}{l}\text { Treated with } \\
\text { hydrazine } \\
(10 \mathrm{mg} / 10 \mathrm{~mL}) \text { for } \\
12-24 \mathrm{~h}\end{array}$ & $15 \mathrm{~h}$ or more & $\begin{array}{c}103 \mathrm{~nm} \text { (length) } \\
68 \mathrm{~nm} \text { (width) }\end{array}$ & $\begin{array}{l}\text { Thin, wide, and } \\
\text { relatively long } \\
\text { rectangular } \\
\text { plates }\end{array}$ & \\
\hline $\begin{array}{l}\text { Kim et al. } \\
{[13]}\end{array}$ & $\begin{array}{l}\text { Chicken, } \\
\text { mouse, fish, } \\
\text { and bovine } \\
\text { bones }\end{array}$ & $75-150 \mu \mathrm{m}$ & $\begin{array}{l}\text { Extraction three } \\
\text { times for } 3 \mathrm{~h} \text { at } 4^{\circ} \mathrm{C} \\
\text { with chloroform and } \\
\text { methanol mixture } \\
(2: 1)\end{array}$ & $15 \mathrm{~h}$ or more & $\begin{array}{c}\text { Bovine bone: } 27.3 \mathrm{~nm} \\
\text { (length) } \\
15.8 \mathrm{~nm} \text { (width) } \\
\text { Mouse: } 21.2 \mathrm{~nm} \\
\text { (length) } \\
12.0 \mathrm{~nm} \text { (width) } \\
\text { Chicken: } 23.3 \mathrm{~nm} \\
\text { (length) } \\
12.2 \mathrm{~nm} \text { (width) } \\
\text { Fish: } 37.3 \mathrm{~nm} \text { (length) } \\
15.4 \mathrm{~nm} \text { (width) }\end{array}$ & Thin plates & $\begin{array}{c}1.63 \text { (bovine } \\
\text { bone) }\end{array}$ \\
\hline $\begin{array}{l}\text { Tong et al. } \\
{[18]}\end{array}$ & $\begin{array}{l}\text { Bovine } \\
\text { cortical bone }\end{array}$ & $75-150 \mu \mathrm{m}$ & $\begin{array}{l}\text { Extraction three } \\
\text { times for } 3 \mathrm{~h} \text { at } 4^{\circ} \mathrm{C} \\
\text { with chloroform and } \\
\text { methanol mixture } \\
(2: 1)\end{array}$ & $15 \mathrm{~h}$ or more & $\begin{array}{c}9 \pm 3 \mathrm{~nm} \text { (length) } \\
6 \pm 2 \mathrm{~nm} \text { (width) } \\
2.0 \pm 1.2 \mathrm{~nm} \\
\text { (thickness) }\end{array}$ & Small platelets & \\
\hline $\begin{array}{l}\text { Eppell et } \\
\text { al. [9] }\end{array}$ & $\begin{array}{l}\text { Bovine } \\
\text { cortical bone }\end{array}$ & $75-150 \mu \mathrm{m}$ & $\begin{array}{l}\text { Extraction three } \\
\text { times for } 3 \mathrm{~h} \text { at } 4^{\circ} \mathrm{C} \\
\text { with chloroform and } \\
\text { methanol mixture } \\
(2: 1)\end{array}$ & $15 \mathrm{~h}$ or more & $\begin{array}{c}12 \pm 2 \mathrm{~nm} \text { (length) } \\
10 \pm 2 \mathrm{~nm} \text { (width) } \\
0.61 \pm 0.19 \mathrm{~nm} \\
\text { (thickness) }\end{array}$ & Plate-like & \\
\hline
\end{tabular}

sintered at $600,700,800,900$, and $1000^{\circ} \mathrm{C}$ for $2 \mathrm{~h}$ respectively. The resultants showed larger crystal size when the temperature was higher than $700^{\circ} \mathrm{C}$, and aggregation of crystals was observed when annealing up to $800^{\circ} \mathrm{C}$ (Figure 5). Moreover, it was also observed that a thermal treatment up to $850^{\circ} \mathrm{C}$ for 1 hour resulted in a carbonate-free HAp [5]. It could be presumed that similar phenomenon might occur during the preparation process of biological apatite with thermal treatment as well. Consequently, the observed crystals may have larger size, changed morphology, and chemical compositions as well as different biological reactivity in comparison to their original form [61]. Hence, it is inappropriate to adopt thermal treatment as the preparation approach when investigating the original crystal characteristics of biological apatite.

3.2. Hydrothermal Hydrolysis with Subcritical Water or Alkaline Solutions. Hydrothermal hydrolysis is a common method used for the synthesis of HAp [69-72]. However, it was less often used in the preparation of biological apatite. The detail was reported as follows. Ground bone powders were mixed with deionized water or alkaline solution (e.g., sodium hydroxide) at a certain solid/liquid ratio and put in a Teflon crucible, which was then placed in a cylindrical hydrothermal reactor made of stainless steel. This reactor was sealed tightly and heated in a silicon oil bath up to $250^{\circ} \mathrm{C}$ for $1 \mathrm{~h}$ or $5 \mathrm{~h}$. Afterwards, the whole reactor was taken out and cooled down by quenching in a great deal of cold water. Finally, the solid product in the reactor was filtered, rinsed with deionized water, and dried [5]. The resultants were free of organic constituents, with maintained carbonate groups and varied crystallinity as well as crystal size.

Such a hydrothermal hydrolysis showed lower temperature in comparison to thermal treatment mentioned above. However, it is still hard to tell whether some unknown effects 


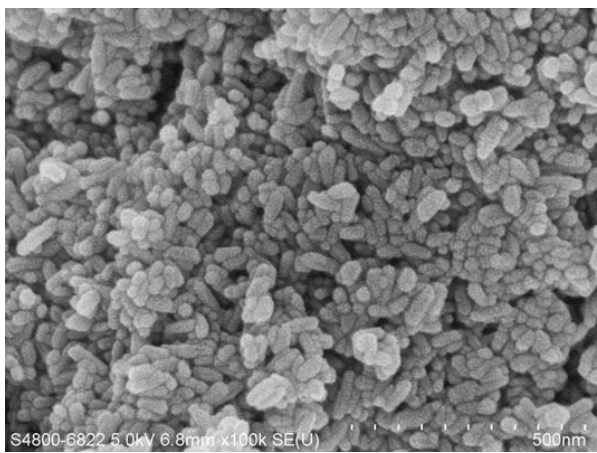

(a)

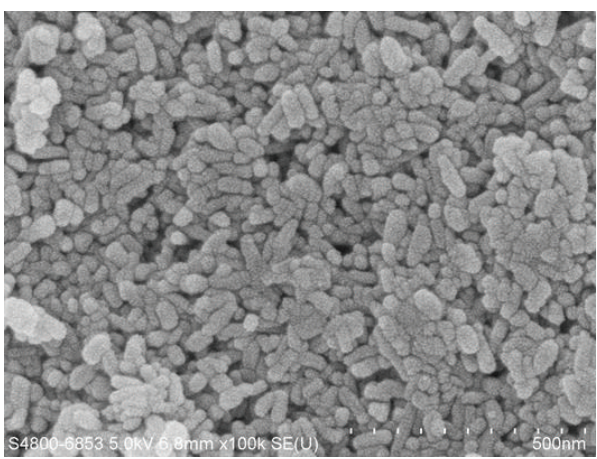

(c)

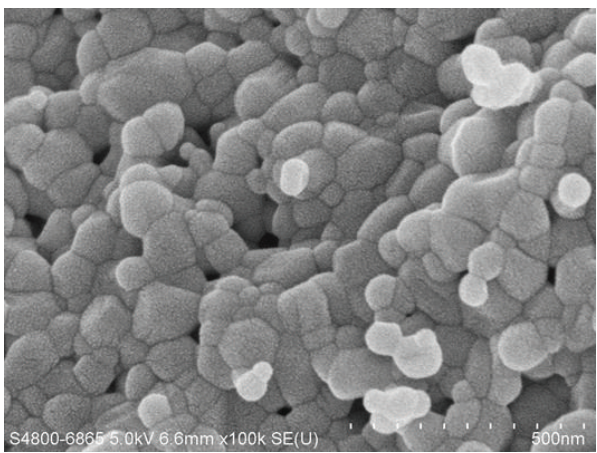

(e)

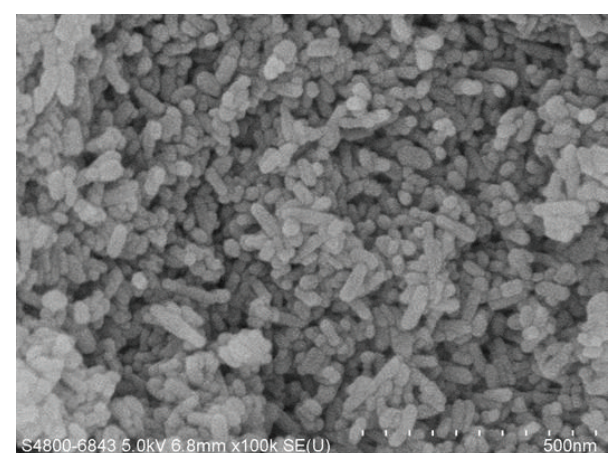

(b)

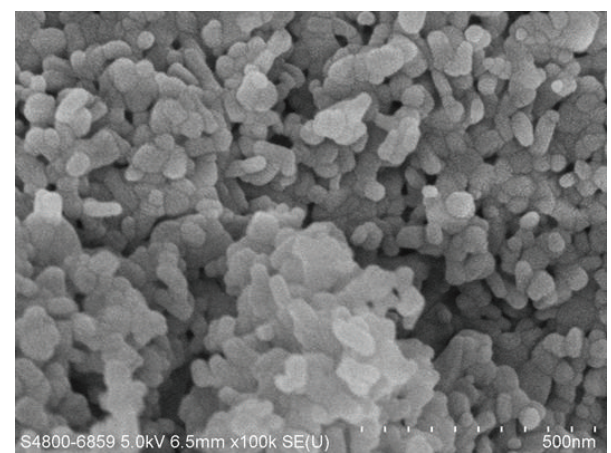

(d)

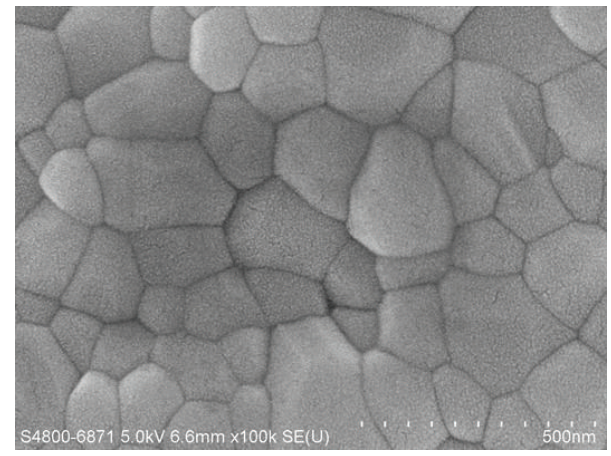

(f)

Figure 5: SEM images of synthetic HAp crystals ((a) HAp raw powder; (b)-(f) HAp-sintered at 600, 700, 800, 900, and 1000 C, resp.): HAp crystals became larger and aggregated when temperature $>800^{\circ} \mathrm{C}$.

were caused by such a temperature with high pressure in the sealed reactor to the crystals or not. Nevertheless, partial dissolution of biological apatite crystals could have been unavoidably caused by the solutions used in the hydrolysis process [13], indicating that hydrothermal hydrolysis may not be viable in the preparation of biological apatite for an original-form investigation.

3.3. Chemical Treatment. Chemical treatment has been used attempting to remove the matrix of bones and teeth so as to obtain biological apatite. In particular, chloroform and methanol [13], hydrogen peroxide [14], acetone [5], and ether and its mixture with acetone $[15,37]$ were adopted as solvents in the elimination of fat. Besides, both alkali salt solutions such as sodium hypochlorite [64, 65] and sodium hydroxide $[11,17,57]$ and nonaqueous hydrazine together with guanidine hydrochloride [13] were applied in the deproteinization process of raw bone samples.

Chemical treatments are regarded as gentle approaches in the preparation of biological apatite, with which the phase transformation of crystals might be avoided and the carbonate groups could be reserved. Nevertheless, it was believed that the adopted chemicals may have an unclear influence on the structure and composition of the crystals [73], which may also affect the examination and application of the final material. In addition, such chemical treatments are usually ineffective and time-consuming. It may take hours or even days in order to remove the organic matrix. Even so, the result may not be so satisfactory, for organic components could be residual [39], especially when the bone samples are oversized and/or the reaction time is insufficient. Consequently, instead of being used independently, chemical 


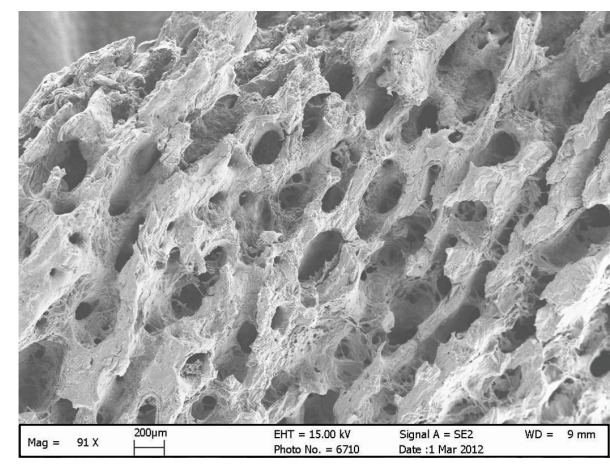

(a)

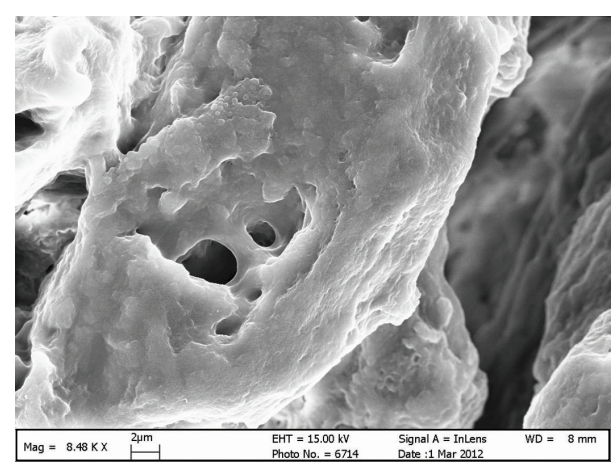

(b)

FIGURE 6: SEM images of porcine bone (supercritical $\mathrm{CO}_{2}$ fluid extraction at $30^{\circ} \mathrm{C}, 35 \mathrm{MPa}, 2 \mathrm{~h}$ ): (a) a porous interconnected bone structure was observed in a low power field; (b) most of the biological apatite crystals were embedded in the residual organic components.

treatment is more often taken as a pretreatment of other methods $[13,14,17,37,57]$. In this case, a chemical treatment may not be necessary as long as the other approaches can eliminate the organic components.

3.4. Supercritical $\mathrm{CO}_{2}$ Fluid Extraction. Supercritical fluid extraction was first invented and applied in some other fields rather than biomaterials science. Once a substance reaches the supercritical state, its physical property becomes an intermediate between the fluid and gas phases. In particular, the substance shows fluid-like density and gas-like diffusivity and viscosity, which enables it to dissolve nonpolar solids $[66,74]$. Even so, by adding certain modifiers such as ethanol and propane, the solubility of both non-polar and polar solids could increase in a supercritical fluid. In particular, $\mathrm{CO}_{2}$ was chosen as the solvent due to its relatively low critical temperature and pressure, coupled with its wide availability, low cost, toxicity, and reactivity. Supercritical $\mathrm{CO}_{2}$ fluid has been used for the extraction of nonpolar and slightly polar species such as alkanes, alcohols, and fats [74].

With supercritical $\mathrm{CO}_{2}$ fluid (SCF), a porous interconnected framework that is composed of biological apatite and proteins could be obtained from animal bones at low temperature [75]. Such a resultant may be probably usable as a carrier or framework in bone engineering. However, it should be noted that most of the proteins like collagens cannot be extracted and would be remained in the bone samples [66] according to the extraction mechanism. In this case, most of the biological apatite crystals are embedded in the residual collagens and are hard to be observed (Figure 6). Thus, supercritical $\mathrm{CO}_{2}$ fluid extraction may be feasible in the preparation of biological apatite using as the framework of bone engineering or even bone substitute. However, sufficient single crystals of biological apatite could hardly be obtained for observation and examination with this method alone.

3.5. Low Power Plasma Ashing. A plasma ashing apparatus was introduced and described in detail in a previous report [76]. This system depends on the reaction between atomic gas (such as oxygen) and target substances (such as organics) to form only gases, that is, $\mathrm{CO}_{2}, \mathrm{H}_{2}$, and $\mathrm{H}_{2} \mathrm{O}$ vapor [77]. After
$15 \mathrm{~h}$ or even longer reaction time, single crystals essentially free of organic constituents were harvested, with the assistance of hydrazine and intermittent ultrasonication [13]. By controlling the reaction conditions, the temperature of the whole reaction system could be lower than $30^{\circ} \mathrm{C}$, preventing the probable effect of high temperature on the morphology, particle size, and crystallinity of the crystals [13, 39]. Besides, no aqueous solution was used during the preparation process of biological apatite crystals, so that the partial dissolution and recrystallization of crystals were avoided.

Upon low power plasma ashing, biological apatite from various species was found to be poorly crystallized crystal with similar morphology, that is, long platelet crystal with wrinkled edges. No rod- or needle-like crystals were observed. Besides, the crystal size varied among different species, but in general the average crystal dimensions were much similar [39].

Given this, low power plasma ashing is probably a feasible method for the maintenance of the original characteristics of biological crystals. Nevertheless, as stated in Table 3, this method was mainly adopted in only one research group, and rare other related reports with this method were found, which might be resulted from the expensive equipment, a relatively complex procedure and long treatment period. Consequently, it seems that more evidence is needed to make this method as a convincing approach in the preparation of biological apatite.

In brief, as stated in Table 4, all approaches above could be applied in obtaining biological apatite. However, it seems that only low power plasma ashing was able to reserve the original characteristics of biological apatite, while either partial dissolution or transformation of the apatite crystals may be caused by the rest. By contrast, other methods are not able to maintain the original status of biological apatite for examination and assessment. However, both thermal treatment and hydrothermal hydrolysis could produce biological apatite for clinical application and reduce the risk of disease infection at the same time. Besides, chemical treatment could work as a supplementary method to other approaches, while supercritical $\mathrm{CO}_{2}$ fluid extraction may be adopted for the framework preparation in bone engineering by controlling the transmission of diseases. 
TABLE 4: Comparison between preparation approaches for biological apatite.

\begin{tabular}{|c|c|c|}
\hline Methods & Advantages & Disadvantages \\
\hline $\begin{array}{l}\text { Thermal treatment } \\
{[5,11,14,16,17,37,57,61]}\end{array}$ & $\begin{array}{l}\text { Relatively low requirement for equipment } \\
\text { Simple procedure } \\
\text { Manageable conditions } \\
\text { Low risk in disease infection } \\
\text { Relatively low cost } \\
\text { Large amount of resultant }\end{array}$ & $\begin{array}{l}\text { Unpredictable effect of heating on apatite } \\
\text { crystals } \\
\text { Properties of resultant vary upon different } \\
\text { sintering conditions }\end{array}$ \\
\hline Chemical treatment $[64,65]$ & $\begin{array}{l}\text { Possible reservation of the original crystal form } \\
\text { and composition } \\
\text { Avoidance of heating effect } \\
\text { Supplementary role for other methods }\end{array}$ & $\begin{array}{l}\text { Residual chemical and organic components } \\
\text { Possible precipitation of amorphous Ca-P } \\
\text { phases [34] } \\
\text { Time consuming }\end{array}$ \\
\hline $\begin{array}{l}\text { Low power plasma ashing } \\
{[13,15,63]}\end{array}$ & $\begin{array}{l}\text { Possible reservation of the original crystal form } \\
\text { and composition } \\
\text { Avoidance of heating effect, partial dissolution, } \\
\text { and recrystallization }\end{array}$ & $\begin{array}{l}\text { Relatively complex procedure } \\
\text { Time consuming } \\
\text { Small amount of resultant } \\
\text { Special equipment are required }\end{array}$ \\
\hline $\begin{array}{l}\text { Supercritical } \mathrm{CO}_{2} \text { fluid } \\
\text { extraction }[66]\end{array}$ & $\begin{array}{l}\text { Relatively low cost } \\
\text { Possible reservation of the original crystal form } \\
\text { and composition } \\
\text { Avoidance of heating effect, partial dissolution, } \\
\text { and recrystallization } \\
\text { Large amount of resultant }\end{array}$ & $\begin{array}{l}\text { Time consuming } \\
\text { Residual organic components } \\
\text { Special equipment are required }\end{array}$ \\
\hline Hydrothermal hydrolysis [5] & $\begin{array}{l}\text { No residual organic components } \\
\text { Simple procedure } \\
\text { Manageable conditions }\end{array}$ & $\begin{array}{l}\text { Special equipment are required } \\
\text { Unpredictable effect of high pressure on } \\
\text { apatite crystals } \\
\text { Properties of resultant vary upon different } \\
\text { hydrolysis conditions }\end{array}$ \\
\hline
\end{tabular}

\section{Conclusion and Perspective}

Together with synthetic HAp, biological apatite plays an important role in various fields. However, a comprehensive understanding of biological apatite has not been achieved due to its complicated basic properties. The consistent and comparable data for its chemical compositions, crystalline characteristics, and solubility were still lacking. Among the various approaches reviewed, there was not a standard or optimal method for the preparation of biological apatite. However, it seems that only low power plasma ashing can protect the apatite crystals from transformation, ionic incorporation, and partial dissolution, although more evidence is needed for convincing its reliability and feasibility. Given all above, more effort may be taken in the improvement of preparation method so as to achieve a better understanding of biological apatite and to improve the clinical performance of bone-based grafting materials.

\section{Acknowledgments}

This work was supported by General Research Fund from Research Grants Council (RGC, HKU 704510P) of Hong Kong. Quan Liu and Shishu Huang are cofirst authors. There is no conflict of interests to report in this paper.

\section{References}

[1] H. R. Wenk and F. Heidelbach, "Crystal alignment of carbonated apatite in bone and calcified tendon: results from quantitative texture analysis," Bone, vol. 24, no. 4, pp. 361-369, 1999.
[2] A. L. Horvath, "Solubility of structurally complicated materials: II. Bone," Journal of Physical and Chemical Reference Data, vol. 35, no. 4, pp. 1653-1668, 2006.

[3] G. Cannizzaro, P. Felice, M. Leone, P. Viola, and M. Esposito, "Early loading of implants in the atrophic posterior maxilla: lateral sinus lift with autogenous bone and Bio-Oss versus crestal mini sinus lift and 8-mm hydroxyapatite-coated implants. A randomised controlled clinical trial," European Journal of Oral Implantology, vol. 2, no. 1, pp. 25-38, 2009.

[4] A. Stavropoulos and T. Karring, "Guided tissue regeneration combined with a deproteinized bovine bone mineral (Bio-Oss) in the treatment of intrabony periodontal defects: 6-year results from a randomized-controlled clinical trial," Journal of Clinical Periodontology, vol. 37, no. 2, pp. 200-210, 2010.

[5] N. A. M. Barakat, K. A. Khalil, F. A. Sheikh et al., "Physiochemical characterizations of hydroxyapatite extracted from bovine bones by three different methods: extraction of biologically desirable HAp," Materials Science and Engineering C, vol. 28, no. 8, pp. 1381-1387, 2008.

[6] C. Zhuofan, H. Baoxin, P. Haobo, and B. W. Darvell, "Solubility of bovine-derived hydroxyapatite by solid titration, $\mathrm{pH} 3.5-5$," Crystal Growth and Design, vol. 9, no. 6, pp. 2816-2820, 2009.

[7] G. Daculsi and B. Kerebel, "Some ultrastructural aspects of biological apatite dissolution and possible role of dislocations," Journal de Biologie Buccale, vol. 5, no. 3, pp. 203-218, 1977.

[8] S. N. Danilchenko, A. V. Koropov, I. Y. Protsenko, B. SulkioCleff, and L. F. Sukhodub, "Thermal behavior of biogenic apatite crystals in bone: an X-ray diffraction study," Crystal Research and Technology, vol. 41, no. 3, pp. 268-275, 2006.

[9] S. J. Eppell, W. Tong, J. L. Katz, L. Kuhn, and M. J. Glimcher, "Shape and size of isolated bone mineralites measured using 
atomic force microscopy," Journal of Orthopaedic Research, vol. 19, no. 6, pp. 1027-1034, 2001.

[10] S. A. Jackson, A. G. Cartwright, and D. Lewis, "The morphology of bone mineral crystals," Calcified Tissue International, vol. 25, no. 3, pp. 217-222, 1978.

[11] A. M. Janus, M. Faryna, K. Haberko, A. Rakowska, and T. Panz, "Chemical and microstructural characterization of natural hydroxyapatite derived from pig bones," Microchimica Acta, vol. 161, no. 3-4, pp. 349-353, 2008.

[12] S. Joschek, B. Nies, R. Krotz, and A. Göpferich, "Chemical and physicochemical characterization of porous hydroxyapatite ceramics made of natural bone," Biomaterials, vol. 21, no. 16, pp. 1645-1658, 2000.

[13] H. M. Kim, C. Rey, and M. J. Glimcher, "Isolation of calciumphosphate crystals of bone by non-aqueous methods at low temperature," Journal of Bone and Mineral Research, vol. 10, no. 10, pp. 1589-1601, 1995.

[14] S. H. Kim, J. W. Shin, S. A. Park et al., "Chemical, structural properties, and osteoconductive effectiveness of bone block derived from porcine cancellous bone," Journal of Biomedical Materials Research B, vol. 68, no. 1, pp. 69-74, 2004.

[15] L. T. Kuhn, M. D. Grynpas, C. C. Rey, Y. Wu, J. L. Ackerman, and M. J. Glimcher, "A comparison of the physical and chemical differences between cancellous and cortical bovine bone mineral at two ages," Calcified Tissue International, vol. 83, no. 2, pp. 146154, 2008.

[16] C. Y. Ooi, M. Hamdi, and S. Ramesh, "Properties of hydroxyapatite produced by annealing of bovine bone," Ceramics International, vol. 33, no. 7, pp. 1171-1177, 2007.

[17] D. S. Seo, Y. G. Kim, and J. K. Lee, "Sintering and dissolution of bone ash-derived hydroxyapatite," Metals and Materials International, vol. 16, no. 4, pp. 687-692, 2010.

[18] W. Tong, M. J. Glimcher, J. L. Katz, L. Kuhn, and S. J. Eppell, "Size and shape of mineralites in young bovine bone measured by atomic force microscopy," Calcified Tissue International, vol. 72, no. 5, pp. 592-598, 2003.

[19] X. Y. Wang, Y. Zuo, D. Huang, X. Hou, and Y. Li, “Comparative study on inorganic composition and crystallographic properties of cortical and cancellous bone," Biomedical and Environmental Sciences, vol. 23, no. 6, pp. 473-480, 2010.

[20] Z. F. Chen, B. W. Darvell, and V. W. H. Leung, "Hydroxyapatite solubility in simple inorganic solutions," Archives of Oral Biology, vol. 49, no. 5, pp. 359-367, 2004.

[21] V. Misra and P. K. Chaturvedi, "Plant uptake/bioavailability of heavy metals from the contaminated soil after treatment with humus soil and hydroxyapatite," Environmental Monitoring and Assessment, vol. 133, no. 1-3, pp. 169-176, 2007.

[22] R. A. Yukna, P. Castellon, A. M. Saenz-Nasr et al., "Evaluation of hard tissue replacement composite graft materials as ridge preservation/augmentation material in conjunction with immediate hydroxyapatite-coated dental implants," Journal of Periodontology, vol. 74, no. 5, pp. 679-686, 2003.

[23] K. L. Lu, X. C. Meng, J. X. Zhang, X. Li, and M. Zhou, "Inhibitory effect of synthetic nano-hydroxyapatite on dental caries," Key Engineering Materials, vol. 336-338, pp. 1538-1541, 2007.

[24] L. C. Palmer, C. J. Newcomb, S. R. Kaltz, E. D. Spoerke, and S. I. Stupp, "Biomimetic systems for hydroxyapatite mineralization inspired by bone and enamel," Chemical Reviews, vol. 108, no. 11, pp. 4754-4783, 2008.

[25] A. Fernández-Pareja, E. Hernández-Blanco, J. M. PérezMaceda, V. J. R. Rubio, J. H. Palazuelos, and J. M. Dalmau, "Prevention of osteoporosis: four-year follow-up of a cohort of postmenopausal women treated with an ossein-hydroxyapatite compound," Clinical Drug Investigation, vol. 27, no. 4, pp. 227232, 2007.

[26] V. Uskoković and D. P. Uskoković, "Nanosized hydroxyapatite and other calcium phosphates: chemistry of formation and application as drug and gene delivery agents," Journal of Biomedical Materials Research B, vol. 96, no. 1, pp. 152-191, 2011.

[27] A. S. Posner, A. Perloff, and A. F. Diorio, "Refinement of the hydroxyapatite structure," Acta Crystallographica, vol. 11, no. 4, pp. 308-309, 1958.

[28] J. C. Elliott, P. E. Mackie, and R. A. Young, "Monoclinic hydroxyapatite," Science, vol. 180, no. 4090, pp. 1055-1057, 1973.

[29] J. C. Elliott, Structure and Chemistry of the Apatites and Other Calcium Orthophosphates, Elsevier, Amsterdam, The Netherlands, 1st edition, 1994.

[30] G. B. Ma and X. Y. Liu, "Hydroxyapatite: hexagonal or monoclinic?” Crystal Growth and Design, vol. 9, no. 7, pp. 2991-2994, 2009.

[31] M. Vallet-Regí, Biomimetic Nanoceramics in Clinical Use from Materials to Applications, Royal Society of Chemistry, Cambridge, UK, 1st edition, 2008.

[32] R. Z. LeGeros, "Calcium phosphate-based osteoinductive materials," Chemical Reviews, vol. 108, no. 11, pp. 4742-4753, 2008.

[33] J. Kolmas, M. Szwaja, and W. Kolodziejski, "Solid-state NMR and IR characterization of commercial xenogeneic biomaterials used as bone substitutes," Journal of Pharmaceutical and Biomedical Analysis, vol. 61, pp. 136-141, 2012.

[34] C. Rey, C. Combes, C. Drouet, and M. J. Glimcher, "Bone mineral: update on chemical composition and structure," Osteoporosis International, vol. 20, no. 6, pp. 1013-1021, 2009.

[35] J. D. Pasteris, B. Wopenka, J. J. Freeman et al., "Lack of OH in nanocrystalline apatite as a function of degree of atomic order: implications for bone and biomaterials," Biomaterials, vol. 25, no. 2, pp. 229-238, 2004.

[36] H. B. Lu, C. T. Campbell, D. J. Graham, and B. D. Ratner, "Surface characterization of hydroxyapatite and related calcium phosphates by XPS and TOF-SIMS," Analytical Chemistry, vol. 72, no. 13, pp. 2886-2894, 2000.

[37] R. Murugan, T. S. S. Kumar, and K. P. Rao, "Fluorinated bovine hydroxyapatite: preparation and characterization," Materials Letters, vol. 57, no. 2, pp. 429-433, 2002.

[38] A. L. Arsenault, "Crystal-collagen relationships in calcified turkey leg tendons visualized by selected-area dark field electron microscopy," Calcified Tissue International, vol. 43, no. 4, pp. 202-212, 1988.

[39] H. M. Kim, C. Rey, and M. J. Glimcher, "X-ray diffraction, electron microscopy, and Fourier transform infrared spectroscopy of apatite crystals isolated from chicken and bovine calcified cartilage," Calcified Tissue International, vol. 59, no. 1, pp. 5863, 1996.

[40] P. Garnier and J. C. Voegel, "Kinetic studies of synthetic and biological apatite dissolution," Journal of Dental Research, vol. 55, p. D154, 1976.

[41] H. B. Pan and B. W. Darvell, "Solubility of hydroxyapatite by solid titration at $\mathrm{pH} 3-4$," Archives of Oral Biology, vol. 52, no. 7, pp. 618-624, 2007.

[42] H. B. Pan, Z. Y. Li, W. M. Lam et al., "Solubility of strontiumsubstituted apatite by solid titration," Acta Biomaterialia, vol. 5, no. 5, pp. 1678-1685, 2009. 
[43] Y. G. Kim, D. S. Seo, and J. K. Lee, "Dissolution of synthetic and bovine bone-derived hydroxyapatites fabricated by hotpressing," Applied Surface Science, vol. 255, no. 2, pp. 589-592, 2008.

[44] K. H. Prakash, R. Kumar, C. P. Ooi, P. Cheang, and K. A. Khor, "Apparent solubility of hydroxyapatite in aqueous medium and its influence on the morphology of nanocrystallites with precipitation temperature," Langmuir, vol. 22, no. 26, pp. 1100211008, 2006.

[45] D. D. Heslop, Y. Bi, A. A. Baig, and W. I. Higuchi, "Metastable equilibrium solubility behavior of carbonated apatite in the presence of solution strontium," Calcified Tissue International, vol. 74, no. 1, pp. 72-85, 2004.

[46] H. Zhuang, A. A. Baig, J. L. Fox et al., "Metastable equilibrium solubility behavior of carbonated apatites in the presence of solution fluoride," Journal of Colloid and Interface Science, vol. 222, no. 1, pp. 90-96, 2000.

[47] H. B. Pan and B. W. Darvell, "Effect of carbonate on hydroxyapatite solubility," Crystal Growth and Design, vol. 10, no. 2, pp. 845-850, 2010.

[48] W. F. Neuman and B. J. Mulryan, "The surface chemistry of bone. VI. Recrystallization in vivo," The Journal of Biological Chemistry, vol. 195, no. 2, pp. 843-848, 1952.

[49] R. M. H. Verbeek, H. Steyaer, H. P. Thun, and F. Verbeek, "Solubility of synthetic calcium hydroxyapatites," Journal of the Chemical Society, Faraday Transactions 1, vol. 76, pp. 209-219, 1980.

[50] H. C. Margolis and E. C. Moreno, "Kinetics of hydroxyapatite dissolution in acetic, lactic, and phosphoric acid solutions," Calcified Tissue International, vol. 50, no. 2, pp. 137-143, 1992.

[51] H. B. Pan, Solubility of Calcium Phosphates and Related Oral Minerals by Solid Titration, The University of Hong Kong, Hong Kong, China, 2007.

[52] M. S. Tung, L. C. Chow, and W. E. Brown, "Hydrolysis of dicalcium phosphate dihydrate in the presence or absence of calcium fluoride," Journal of Dental Research, vol. 64, no. 1, pp. 2-5, 1985.

[53] A. Chhettry, Z. R. Wang, J. Hsu et al., "Metastable equilibrium solubility distribution of carbonated apatite as a function of solution composition," Journal of Colloid and Interface Science, vol. 218, no. 1, pp. 57-67, 1999.

[54] Å. Bengtsson, A. Shchukarev, P. Persson, and S. Sjöberg, "A solubility and surface complexation study of a non-stoichiometric hydroxyapatite," Geochimica et Cosmochimica Acta, vol. 73, no. 2, pp. 257-267, 2009.

[55] H. Eslami, M. Solati-Hashjin, and M. Tahriri, "Effect of fluorine ion addition on structural, thermal, mechanical, solubility and biocompatibility characteristics of hydroxyapatite nanopowders," Advances in Applied Ceramics, vol. 109, no. 4, pp. 200-212, 2010.

[56] S. Sprio, A. Tampieri, E. Landi et al., "Physico-chemical properties and solubility behaviour of multi-substituted hydroxyapatite powders containing silicon," Materials Science and Engineering C, vol. 28, no. 1, pp. 179-187, 2008.

[57] R. Murugan, S. Ramakrishna, and K. P. Rao, "Nanoporous hydroxy-carbonate apatite scaffold made of natural bone," Materials Letters, vol. 60, no. 23, pp. 2844-2847, 2006.

[58] D. S. Seo and J. K. Lee, "Dissolution of human teeth-derived hydroxyapatite," Annals of Biomedical Engineering, vol. 36, no. 1, pp. 132-140, 2008.
[59] A. I. Pearce, R. G. Richards, S. Milz, E. Schneider, and S. G. Pearce, "Animal models for implant biomaterial research in bone: a review," European Cells and Materials, vol. 13, pp. 1-10, 2007.

[60] H. L. Rosenthal, M. M. Eves, and O. A. Cochran, "Common strontium concentrations of mineralized tissues from marine and sweet water animals," Comparative Biochemistry and Physiology, vol. 32, no. 3, pp. 445-450, 1970.

[61] S. H. Rhee, H. N. Park, Y. J. Seol, C. Chung, and S. H. Han, "Effect of heat-treatment temperature on the osteoconductivity of the apatite derived from bovine bone," Key Engineering Materials, vol. 309-311, pp. 41-44, 2006.

[62] H. B. Pan, Z. Y. Li, T. Wang et al., "Nucleation of strontiumsubstituted apatite," Crystal Growth and Design, vol. 9, no. 8, pp. 3342-3345, 2009.

[63] Z. Y. Li, W. W. Lu, L. F. Deng et al., "The morphology and lattice structure of bone crystal after strontium treatment in goats," Journal of Bone and Mineral Metabolism, vol. 28, no. 1, pp. 2534, 2010.

[64] X. Su, K. Sun, F. Z. Cui, and W. J. Landis, “Organization of apatite crystals in human woven bone," Bone, vol. 32, no. 2, pp. 150-162, 2003.

[65] S. Weiner and P. A. Price, "Disaggregation of bone into crystals," Calcified Tissue International, vol. 39, no. 6, pp. 365-375, 1986.

[66] C. F. Chen, C. S. Chang, Y. P. Chen, T. Lin, C. Su, and S. Lee, "Applications of supercritical fluid in alloplastic bone graft: a novel method and in vitro tests," Industrial and Engineering Chemistry Research, vol. 45, no. 10, pp. 3400-3405, 2006.

[67] K. D. Rogers and P. Daniels, "An X-ray diffraction study of the effects of heat treatment on bone mineral microstructure," Biomaterials, vol. 23, no. 12, pp. 2577-2585, 2002.

[68] Y. X. Pang and X. Bao, "Influence of temperature, ripening time and calcination on the morphology and crystallinity of hydroxyapatite nanoparticles," Journal of the European Ceramic Society, vol. 23, no. 10, pp. 1697-1704, 2003.

[69] M. G. Ma, "Hierarchically nanostructured hydroxyapatite: hydrothermal synthesis, morphology control, growth mechanism, and biological activity," International Journal of Nanomedicine, vol. 7, pp. 1781-1791, 2012.

[70] K. Li and S. C. Tjong, "Hydrothermal synthesis and biocompatibility of hydroxyapatite nanorods," Journal of Nanoscience and Nanotechnology, vol. 11, no. 12, pp. 10444-10448, 2011.

[71] J. Klinkaewnarong, E. Swatsitang, and S. Maensiri, "Synthesis and characterization of high purity hydroxyapatite nanorods by hydrothermal technique," Journal of Nanoscience and Nanotechnology, vol. 11, no. 10, pp. 8831-8834, 2011.

[72] S. P. Parthiban, K. Elayaraja, E. K. Girija et al., "Preparation of thermally stable nanocrystalline hydroxyapatite by hydrothermal method," Journal of Materials Science: Materials in Medicine, vol. 20, supplement 1, pp. S77-S83, 2009.

[73] T. Sakae, H. Mishima, and Y. Kozawa, "Changes in bovine dentin mineral with sodium hypochlorite treatment," Journal of Dental Research, vol. 67, no. 9, pp. 1229-1234, 1988.

[74] C. L. Phelps, N. G. Smart, and C. M. Wai, "Past, present, and possible future applications of supercritical fluid extraction technology," Journal of Chemical Education, vol. 73, no. 12, pp. 1163-1168, 1996.

[75] L. Bi, D. Li, M. Liu et al., "The influence of approaches for the purification of natural cancellous bone grafts: morphology, 
microstructure, composition, strength and biocompatibility study," Materials Letters, vol. 64, no. 19, pp. 2056-2059, 2010.

[76] J. E. Patterson, “Oxygen plasma asher," Analytical Chemistry, vol. 51, no. 7, pp. 1087-1089, 1979.

[77] X. J. Dai, "Kinetic model of an RF discharge in oxygen," Australian Journal of Physics, vol. 49, no. 6, pp. 1169-1180, 1996. 

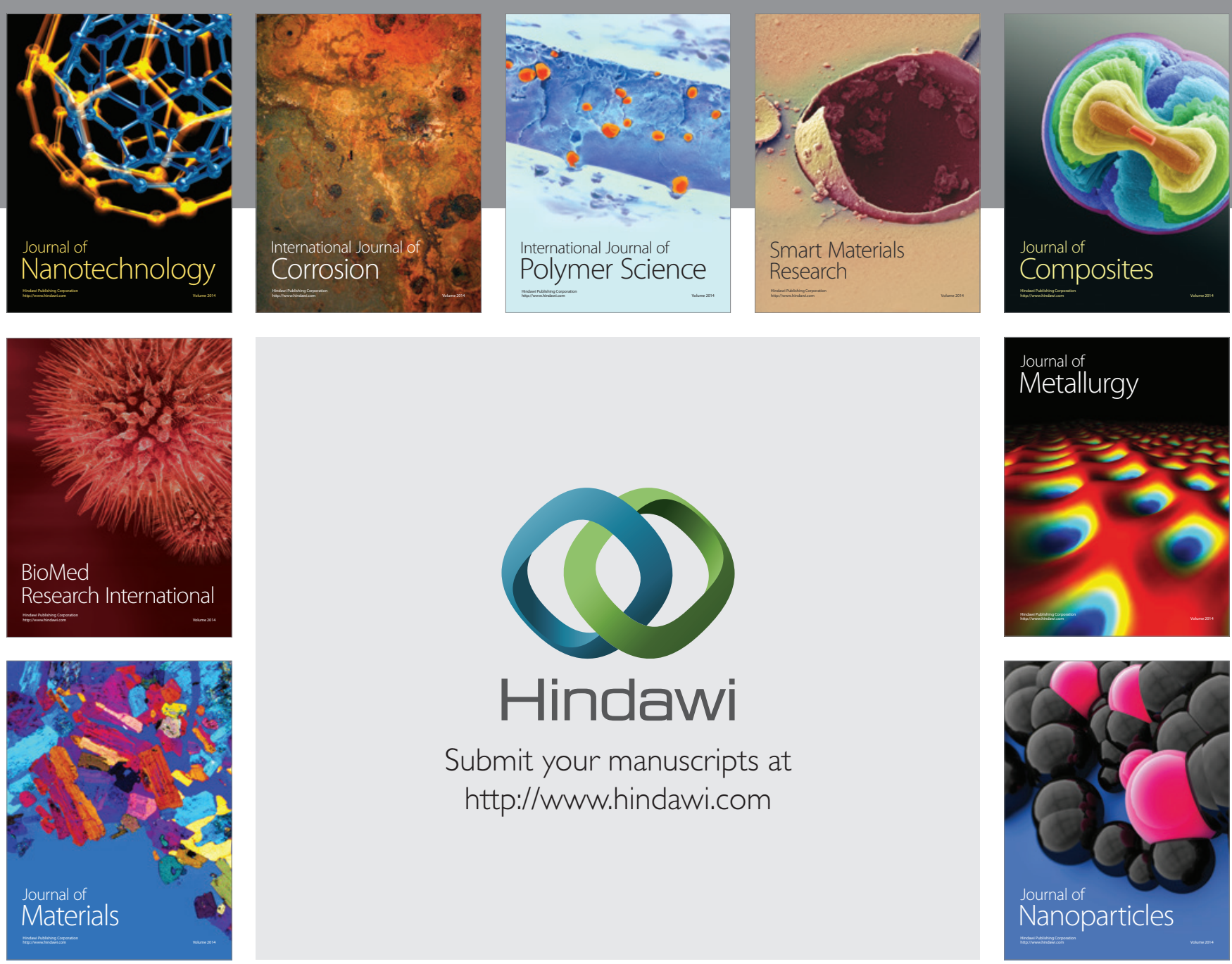

Submit your manuscripts at http://www.hindawi.com
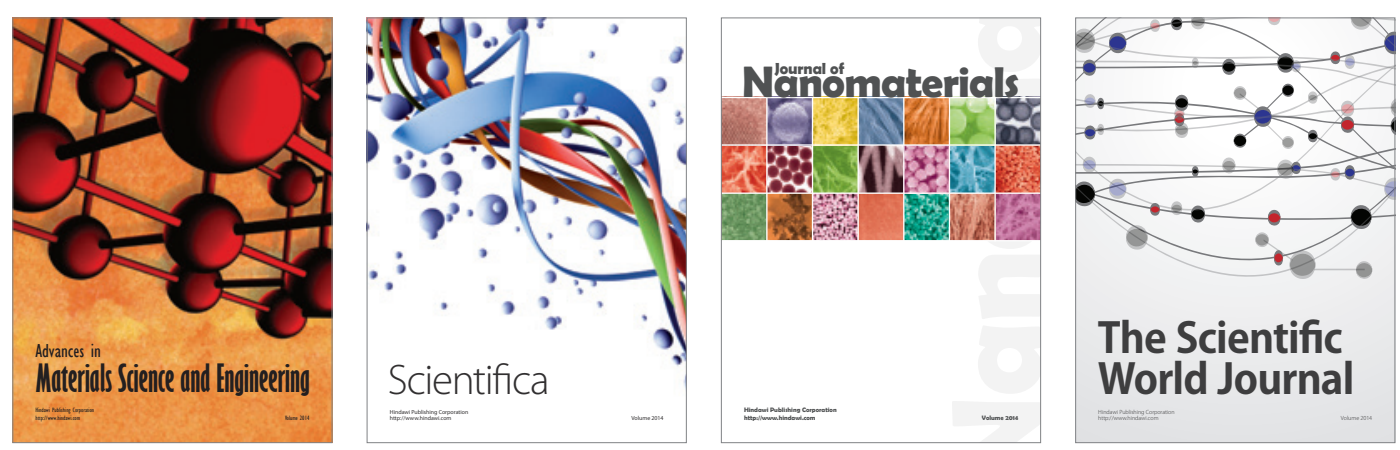

\section{The Scientific World Journal}
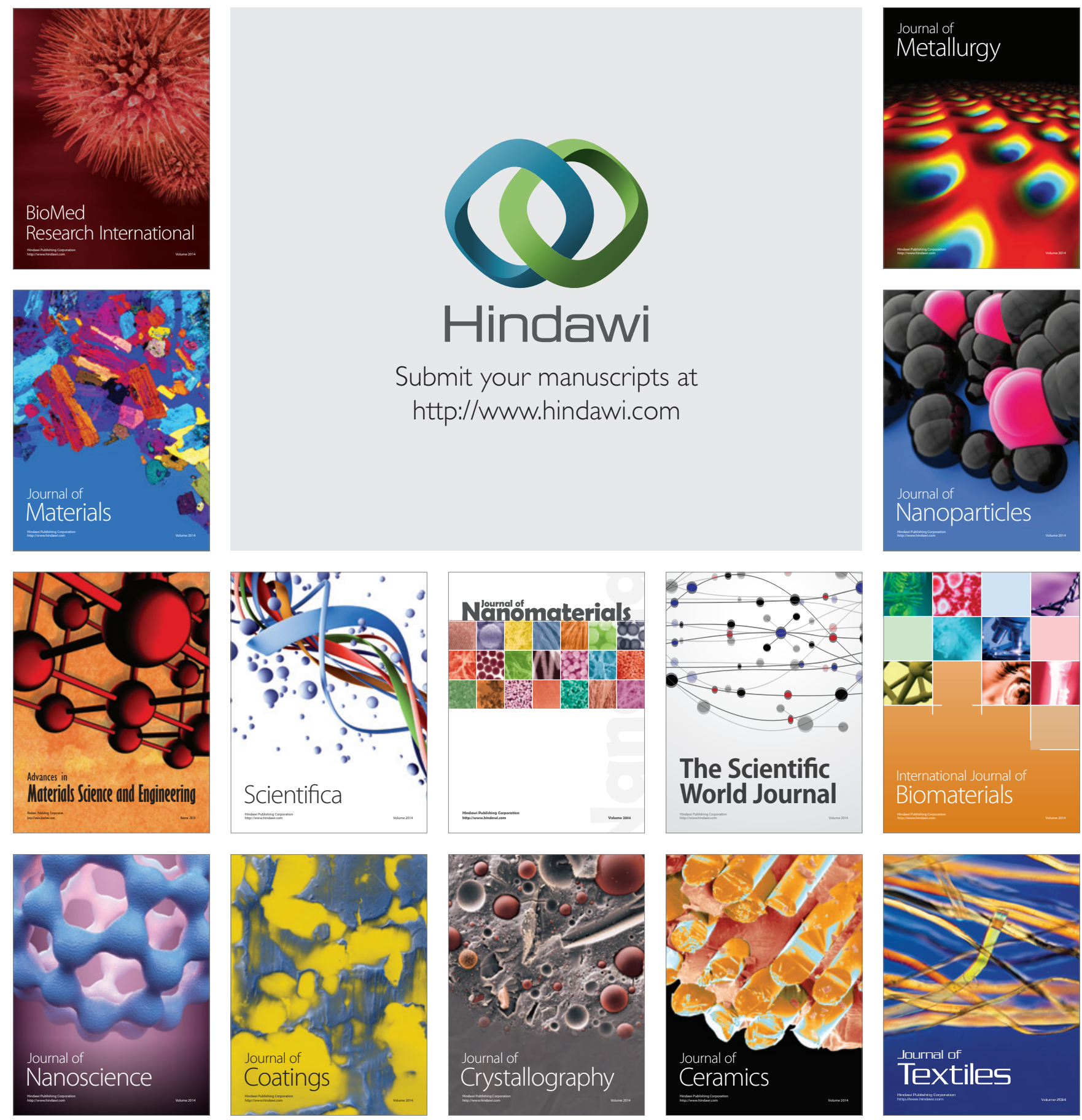